\title{
Global Crises and Corporate Reorganisation Methods
}

\author{
Éva Pálinkó1, Kinga Pétervári \\ 1 Department of Finance and Accounting, Institute of Business Economics, Eötvös Loránd University (ELTE), H-1053 Budapest, \\ Egyetem tér 1-3., Hungary \\ 2 Department of Management and Business Law, Institute of Business Economics, Eötvös Loránd University (ELTE), \\ H-1053 Budapest, Egyetem tér 1-3., Hungary \\ *Corresponding author, e-mail: petervari@gti.elte.hu
}

Received: 06 April 2019, Accepted: 04 October 2021, Published online: 07 February 2022

\begin{abstract}
Despite many regulatory changes there are still no sound reorganisation possibilities for financially distressed companies in Hungary. The current crisis of 2020 due to the pandemic is going to trigger mass liquidations especially there where the bankruptcy rules are ineffective. There is no efficient risk and resource allocation if there is no reasoning and the financial and economic criteria necessary for a proper bankruptcy management are not taken into consideration in the reorganisation procedure. This article is based on primary research conducted in 2014 and a further analysis of the problem published in the Eurasian Studies in Business and Economics in 2020 (Pálinkó and Pétervári, 2020). The conclusion is that the financial variables are seemingly irrelevant in decisionmaking. The bankruptcy procedure has become a useful tactic for the owner-management to keep their position and protected status for as long as possible even at the expense of the divergent creditors. There is a genuine need for a different model in Hungary, one in which financially rational decisions are not dysfunctional. We have found that time is the most important factor here. It is therefore suggested that the rules should be designed so that the companies be motivated to file for bankruptcy in time. This design is the automated mandatory auction bankruptcy procedure or its pre-pack version.
\end{abstract}

\section{Keywords}

Budapest, Hungary, bankruptcy, corporate reorganisation, fiduciary duty, pre-pack bankruptcy, auction bankruptcy, information asymmetry, timely filing

\section{Introduction}

\subsection{Aim of the article}

Ever since the fall of the socialist regime it has been a common experience in the Budapest region, Hungary that there is no sound selection procedure for financially distressed companies. The financial and economic criteria necessary for a proper management of bankruptcies have not been worked out with a view to promoting effective risk and resource allocation and to achieve an effective reorganisation for both creditors and debtors or a proper exit from the market. This article is based on primary research focusing on the impact of bankruptcy regulatory changes in Hungary after the 2008 global financial crisis.

The main finding is that companies in Hungary file for bankruptcy way too late. The chances of reorganisation are already minuscule right at the time of filing. The bankruptcy procedure has become a lengthy and useful tactic for the management/owners to keep their position and protect their status for as long as they can.
Hungary has an underdeveloped, distorted financial market, where information is a special commodity and directors/owners may abuse this at the expense of (unsecured) creditors. Creditors are very diverse. The financial markets in Hungary are heavily influenced by a few big banks (secured creditors). Yet the overwhelming majority of companies are small or medium-sized enterprises (SMEs) which often do not have access to bank loans. Hence, these companies are often financed by commercial loans (unsecured creditors). This, in turn, makes companies vulnerable to debt chains and debt queues. Bankruptcy procedures should therefore be designed so that these, otherwise viable, value producing, companies can be given another chance. This relatively wide discrepancy among the classes of creditors in Hungary renders the effects of bankruptcy regulations quite confusing. As in most European countries, bankruptcy regulations are creditor friendly and protect secured creditors (banks or 
senior creditors), often at the expense of unsecured creditors (suppliers, mostly). It is suggested that the automatic mandatory auction bankruptcy procedure (Swedish model) may be an efficient solution to such problems. We suggest that bankruptcy rules should maximise the asset value of the financially distressed company, often meaning that a quick sale of the company as such would be preferable. Hence, after the transaction, an informed decision could be made by the buyer (perhaps former creditor) and the owner being the same person. Economically speaking, this would make for a truly efficient financial decision, since all information would be at his or her disposal. The emphasis here is also on the time span. For biased information, in given cases, a swift transaction may be a fair trade off (Sowell, 1996). In Hungary, in the absence of market pressure, this auction procedure should provide for a kind of an economically calculable threat to market participants and other decision makers.

\subsection{Need for reorganisation}

Recently, the reorganisation procedure has stood at the centre of focus of insolvency procedures almost all over the globe, mostly taking the US Chapter 11 as an example of a well-functioning solution. Even if it is vehemently criticised (LoPucki and Kalin, 2001; LoPucki and Doherty, 2015), several empirical studies justify the efficiency of this kind of reorganisation for most interested parties in companies (Bris et al., 2006; Corbae and D'Erasmo, 2017; Gine and Love, 2010). It is also affirmed that it enhances productivity growth in companies and thereby contributes to the common good and economic welfare of the entire economy (Ayotte and Skeel, 2010).

This attitude is well documented in a new study by the EU on business failures and insolvency (McCormack et al., 2016). This is naturally based on the initiatives of many Member States. In the past 2-3 decades, most European countries tried to introduce a much more flexible bankruptcy regime, because the vast majority of bankruptcy procedures had turned into liquidation.

Although for very different reasons, the picture is not at all different in Central-Europe, where the otherwise preferred bankruptcy procedures turn systematically into liquidation. Here financially distressed companies tend to avoid reorganisation due to the wearisome and unpredictable process of bankruptcy and choose instead a relatively quicker solution in liquidation (Damijan, 2014; Janda and Rakicova, 2014).

One major difference between the American and the European rules is the aspect or the notion of the regulations applicable to insolvency. While the US attitude towards bankruptcy is to view it as something normal ("it happens"), the Europeans deal with it as something wrong, as something which should be prevented. The former attitude embraces it as an outcome of the nature of the market, whereas the latter sees it rather as a defect, as a frustration of contract (Brouwer, 2006).

It is a commonplace to say that the continental legal culture is different from the common law countries which ultimately makes for a different legal and economic environment for the procedures relating to financially distressed companies (Beck and Levine, 2004; Brouwer, 2006; Djankov et al., 2003). The USA's Chapter 11, which includes reorganisation procedures, is a more malleable system with more room for negotiations among the stakeholders of the company than is provided for in the continental bankruptcy regime. Throughout the procedures of this latter system there is an inherent focus on creditor protection, rather than on balancing the interests of the debtor, the directors, and the different classes of creditors. However, the UK market-based system, despite being creditor-friendly, has become more flexible providing several ways to support the bargaining possibilities of the actors in the procedure.

In general, stock markets are smaller in Europe than in the USA, and so company financing is more dependent on bank loans than equity investment. The strict protection of creditors' rights is therefore essential to the viability of financial markets here.

The typical European system of bankruptcy operates in a market dominated by small enterprises and banks. Studies in the field indicate that most reorganisation procedures in many European countries sooner or later turn into liquidation. The variation of the figures for different countries is also explained by the legal environment, and the legal culture of the given market. Recent research carried out in countries with French civil law traditions indicates that in Belgium $79 \%$ of companies under bankruptcy procedure end up being liquidated, while the figure is $72 \%$ in France. This figure, however, is $46 \%$ in England, a common law country (Dewaelheyns and Van Hulle, 2009). This is no wonder, though, since in the former legal environment, the most influential creditors, the banks, can acquire leverage over shareholders and non-secured creditors.

However, the structure and the cultural legacy of the court systems also supports this discrepancy. The judiciary in the common law system is endowed with wider autonomy and less procedural formalism (Beck and Levine, 2004; Djankov et al., 2003). Originally, bankruptcy 
cases belonged to the realm of torts and were developed case by case, with reasoning in the USA, for example, focusing on bargaining and negotiations from a very business-oriented point of view. The French and German civil law traditions on the other hand are based on the Roman law concept of pacta sunt servanda, contracts must be fulfilled. This is guaranteed by states, which are, in exchange, legitimised. Legally speaking therefore, this is the common point of reference in the continental attitude towards creditor protection, with certain exceptions of course, such as the Netherlands, for example. The fact that a certain legacy is still capable of affecting legislation and dominating outcomes can well be evidenced by both comparative and historical analysis (de Ruysscher, 2018; Pétervári, 2018).

This divergence in the focus of bankruptcy procedures, namely that the US rules are debtor-friendlier, and the Europeans are creditor-friendlier as a starting point, is still quite manifest.

This article is structured as follows: firstly, the global economic and legal reactions to crises are discussed relative to the primary research in Hungary (Section 2); secondly, the results of the primary research study are described (Section 3); and thirdly, the possible application of the recommended institutions will be taken into consideration (Section 4).

\section{Crises and the need for reorganisation}

The global financial crisis of 2008 resuscitated the debate on corporate reorganisation procedures all over the markets. In other words, the crisis triggered a market clean-up and bankruptcy legislation that provided a solution through preferring corporate reorganisation over liquidation procedures. Such a preference may be sound, if the illiquidity of an otherwise viable company is mostly due to the external impact of a critical situation in the market, such as supply chain debt, or a debt queue. Although this viable company would, otherwise, be profitable, it faces problems with paybacks.

The aim of reorganisation procedures is, in such cases, to provide for a preliminarily friendlier environment for a possible continuation of the business operations of the company if it is capable, and/or to liquidate it, if it is incapable, as quickly as possible.

\subsection{Financial efficiency criteria of the corporate crisis management}

The paramount financial criteria defining whether a financially distressed company is to be reorganised or rather liquidated are quite well-known. A financially distressed company is viable if the value of the continuation of the business $\left(V_{C}\right)$ exceeds the value of the liquidation of the company $\left(\mathrm{V}_{\mathrm{L}}\right)$. In other words, if the expectations are that a company, in financial distress, is going to create value, it is worth granting it another chance. Otherwise, it should be wound up or liquidated. Hence, if $V_{L}>V_{C}$, then a reasonable decision would be to exit the market. If on the other hand $V_{C}>V_{L}$, then the best decision would be to draw up a reorganisation plan and drive back the company to the value producing track. This is the basic notion which facilitates efficient total capital allocation and serves the interests of all participants, too. The role of bankruptcy rules is to support the making of such an informed decision by the interested parties.

However, these criteria operate in perfect markets and so need to be fine-tuned. Most importantly, the creditors do not make up a homogeneous set. Some of them are protected by mortgage or lien and depending on the rules may get even total compensation before other creditors do. Consequently, provided that the findings support a reorganisation, the efficiency criteria need to consider the following.

The reorganisation and revitalisation of the company is possible unless and until the difference between the liquidation value and the reorganisation value covers the costs $(\mathrm{T})$ of the reorganisation:

$\mathrm{V}_{\mathrm{C}}-\mathrm{V}_{\mathrm{L}}>\mathrm{T}$,

$\mathrm{V}_{\mathrm{C}}-\mathrm{V}_{\mathrm{L}}-\mathrm{T}>\mathrm{O}$

This is the economic efficiency prerequisite of the reorganisation.

The coalition of the creditors should prefer reorganisation over liquidation if the value of the company in the market exceeds the total sum of the actual compensation awarded to the senior (secured) creditors and the actual costs of the reorganisation. This actual compensation awarded to the senior (secured) creditors is the difference (s) between the due and the remaining negotiated amount in the creditors' settlement:

$\mathrm{V}_{\mathrm{C}}>(1-\mathrm{s}) \mathrm{D}+\mathrm{T}$,

$\mathrm{V}_{\mathrm{C}}-(1-\mathrm{s}) \mathrm{D}-\mathrm{T}>\mathrm{O}$.

Timing is also a further condition of a reasonable decision. Bankruptcy has to be declared in the financially relevant and efficient time, i.e. when the status quo of the company is $\mathrm{V}=\mathrm{D}$. ( $\mathrm{V}$ : the liquidation (market) value of the company, D: the debt value of the company). When $\mathrm{V}=0$, the loss of the company is irreversible, it would be clearly too late to file for bankruptcy, liquidation is inevitable. 
The access to information is yet another crucial element of a deliberate decision-making. Since there are no perfect markets, the participants have not only skewed information but some of them have more than the others depending upon the given situation (information asymmetry). The owners (shareholders), the managers and the creditors, let alone other stakeholders, are differently equipped to get information on the present value or the future expectations of the company and so it is salient to know who decides on reorganisation issues or a preference over liquidation. Owners tend to have the least information, since they choose not to operate the company (unless in small businesses the owner is the manager of the company too), banks can have easier access to information than other commercial creditors and managers are usually the masters of such information. This interest-related information asymmetry often causes unnecessary delays in the decision-making and jeopardises the efficient allocation of resources and risks.

Thus, in a non-perfect market where information is not equally accessible and the value of the company is hard to be estimated, the information asymmetry makes it indispensable to set up a bankruptcy procedure that promotes the proper social total capital allocation and protects the creditors.

\subsection{Reorganisation rules supporting the efficient decisions: the Hungarian example}

Although a perfect market would not require the institutions of creditor protection, the existing markets are far from perfect. Information is not equally accessible to all stakeholders and so the decision whether to liquidate or reorganise a company often causes ineffective results (the agency problem). The economic function of reorganisation rules, therefore, is to ensure protection to the creditors and/or the debtors and thereby to efficiently allocate capital either by promoting a reorganisation plan or a creditors' agreement, or by liquidating the company in an organised way.

A basic principle of economics is, that in a perfect market, in the long run, market forces drive the market to an equilibrium. Thus, a company failing to produce at least normal profit in the long run is going to go bankrupt. Stakeholders however may not see these problems until the company publicly declares bankruptcy. If illiquidity is caused by irrational management (ROIC $<$ WACC, i.e. the Return on Invested Capital is less than the Weighted Average Cost of Capital), then the value destruction status - even without further loans - increases the equity leverage (D/E, Debt/Equity ratio). In such a debt spiral, the value of the debt (D) may finally reach or exceed the value of the company (V), meaning that the cause of illiquidity is actual lack of assets.

The economically relevant content of the bankruptcy rule in case of financially distressed companies stems from three groups of factors: operation inefficiency, high financial leverage due to the lack of value production, and illiquidity. In a perfect market, as indicated, stakeholders would have all information necessary to tell whether a company should be saved $\left(\mathrm{V}_{\mathrm{L}}<\mathrm{V}_{\mathrm{C}}\right)$ or liquidated $\left(\mathrm{V}_{\mathrm{L}}>\mathrm{V}_{\mathrm{C}}\right)$, and the rules would not matter.

The rules, however, do matter. Our primary research of 2014 sets out to establish whether the introduction of a market-friendly liquidation procedure (1994), followed by an amendment in favour of reorganisation over liquidation procedures (2009) would make any difference to the attitudes of companies. It sought to find out whether changes in the rules trigger different adjusting behaviour in the decision-making of the interested parties and thereby enhance efficient portfolio management regarding financially distressed companies.

The following is based on primary research focusing on the effect of bankruptcy regulatory changes in Hungary after the 2008 global financial crisis. Act No. LI of 2009, amended the then existing bankruptcy rules and promoted reorganisation procedures as opposed to liquidation. We analyse the attitudes of the Hungarian companies in a creditor-friendly environment towards reorganisation possibilities and examine the outcomes of these procedures. The basic premise underpinning all of the research is that to achieve an efficient capital allocation, the financially reasonable deliberate decisions in the bankruptcy procedures should embrace creditor protection.

Our working hypothesis was that in a crisis, the promotion of reorganisation procedures for bankrupt companies as opposed to liquidation, should further the continuation of otherwise viable companies if the reason for the financial distress was an external cause, such as a suppliers debt queue or a chain of debt, rather than the potential of the company. The results of the research demonstrate that in fact there was no such significant relation between the new rules and the attitude of the companies and their stakeholders. Consequently, the final proposal is that there is a genuine need for a different model for bankruptcy procedures in Hungary.

\subsection{Method and sample of research study}

The research was carried out in 2014, in the BudapestCapital Regional Court. It focused on the new bankruptcy procedures right after the crisis driven amendments of 2009. 
Since this Court collects the necessary data for liquidation and reorganisation procedures separately, one could easily distinguish those cases which included reorganisation procedures, at least at the time of filing. Also, the Court had separate records of the cases which ended with a settlement and those which did not. There were 332 filings with this Court for reorganisation procedures in 2009-2014.

Further financial data on the relevant companies were collected from the Amadeus database. These data include financial statements, balance sheets and other public information, such as corporate governance statements or the legal structure of the companies, extending from a few years before and to a few years after bankruptcy was filed for. Amadeus provides 10 years of coverage for such data.

$45.53 \%$ of the total cases counted on a 5-year average were filed with the Court as seen in Fig. 1. And since there is a correlation between the fate of the cases nationwide and the cases in the municipality our primary research had a focus in the cases in the municipality, the BudapestCapital Regional Court. The main and rather simplistic reason for such a correlation may be the lack of discretionary power of the courts and the rather administrative way of applying the bankruptcy rules regardless of their location.

Out of those 332 filings (total-pool) 97 cases (smallpool) were processed entirely. While the thus examined small-pool cases were read and analysed, those which finally ended up in liquidation could not be included in this study, because procedures had not yet been closed at that time. Table 1. demonstrates the way filings for reorganisation ended. There were 307 companies out of 332 which could be identified in the Amadeus Database. We therefore focused on these 307 . The bankruptcy procedures were finished in 288 cases and 19 procedures were still open, see Table 1.

\subsection{Financial results of companies before filing for reorganisation}

The analysis focuses on the reasoning behind decision-making about the reorganisation of these financially distressed companies. The specific questions are:

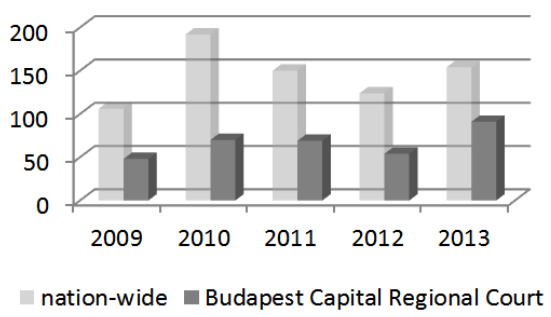

Fig. 1 Numbers of cases of filing for bankruptcy; Sources: KSH (Hungarian Office of Statistics)
Table 1 Various filings for reorganisation at Budapest-Capital

Regional Court, depending on how they ended (2009-2014)

\begin{tabular}{|c|c|c|c|c|}
\hline \multirow{2}{*}{\multicolumn{2}{|c|}{$\begin{array}{l}\text { End of procedure in filings } \\
\text { for reorganisation }\end{array}$}} & \multicolumn{2}{|c|}{ Number of cases } & \multirow{2}{*}{$\begin{array}{c}\% \text { of } \\
\begin{array}{c}\text { reorganisation } \\
\text { filings }\end{array} \\
\text { Total-pool }\end{array}$} \\
\hline & & $\begin{array}{c}\text { Total- } \\
\text { pool }\end{array}$ & $\begin{array}{l}\text { Small- } \\
\text { pool }\end{array}$ & \\
\hline \multicolumn{2}{|c|}{ Settlement } & 79 & 34 & $27 \%$ \\
\hline \multicolumn{2}{|c|}{ Liquidation } & 167 & - & $58 \%$ \\
\hline \multirow{3}{*}{ Refusal } & $\begin{array}{l}\text { Documents not } \\
\text { completed }\end{array}$ & 21 & 17 & $7 \%$ \\
\hline & $\begin{array}{l}\text { Previous } \\
\text { liquidation }\end{array}$ & 10 & 10 & $3 \%$ \\
\hline & $\begin{array}{l}\text { Termination of } \\
\text { procedure }\end{array}$ & 5 & 4 & $2 \%$ \\
\hline \multicolumn{2}{|c|}{ Other termination } & 6 & 6 & $2 \%$ \\
\hline \multicolumn{2}{|l|}{ Total } & 288 & 71 & $100 \%$ \\
\hline
\end{tabular}

Sources: Amadeus database and the Budapest-Capital Regional Court.

1. whether historical data were used and influenced the reorganisation plan, and how well it was applied and/or

2. whether the expectations of these companies were shown, argued, or considered in the reorganisation plan.

Again, as indicated, correct financial decisions could only be made if information is in the market and easily, equally accessible to all stakeholders. Yet, Hungarian companies are characteristically not listed on stock exchange, and thus historical data are the most important information about a company for the stakeholders. For this reason, our research focuses on such data. Further, this primary research also includes thorough scrutiny of reorganisation documents in the case of the 79 companies chosen, to facilitate analysis of the reasons behind the settlements or creditors' agreements in the reorganisation procedures.

As a first step, we examined the value parameters indicating the severity of the financial distress of the company, to assess whether there was a significant difference between those companies which ended up being reorganised and those that were liquidated. The data were drawn from the financial statements of the companies. Two groups were formed from the 307 bankrupted companies: the group of companies remaining in reorganisation procedure (79) and the group of companies which ended up in liquidation procedure due to a failure to come to a creditors' agreement (or settlement) (167), Table 1.

Here we applied a static analysis of the fundamental data in the annual statements of the companies before they 
filed for bankruptcy. Then the companies under reorganisation procedure were allocated indicators believed to allow a proper examination of the viability of the companies under scrutiny by providing a fair view of operation efficiency, financial structure, and liquidity. The year of filing for bankruptcy was taken as a starting point and every subsequent year of operation from then on was taken into consideration. This analysis also included the median values of the indicators selected to measure the viability of the companies in both groups.

It is conspicuous from the analysis of historical data on value-production that there are no significant differences between the two groups of companies before the date of filing for bankruptcy. These data focus on the year of filing for bankruptcy (' $\mathrm{T}$ '), especially on operation efficiency data, and the financial structure (equity leverage) and liquidity data of the given company.

Figs. 2 to 5 demonstrate the critical values of the parameters used in the analysis as part of the descriptive statistics, such as operation efficiency, indebtedness, and liquidity. It also shows the relation of the companies not reaching or exceeding the critical value of the selected financial parameters in the group of companies with agreements and in the group of companies that ended up in liquidation.

In the case of operation efficiency performance, a zero result for the net income from the assets $(\mathrm{NI} / \mathrm{TA}=0)$ was applied as the critical value. If the NI/TA ratio is below zero, it means that the company cannot cover even its accounting costs, and it is therefore impossible to secure

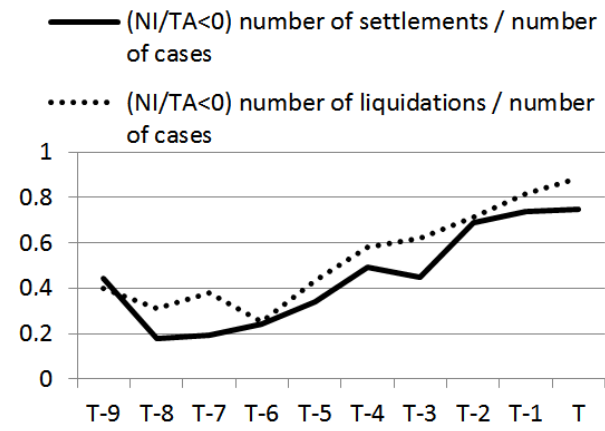

Fig. 2 Numbers of the companies in group with agreements and in group under liquidation procedures. In these cases, the operation efficiency parameters had been below the critical value

$(\mathrm{NI} / \mathrm{TA}<0)$ years before the filing for bankruptcy; Sources: Own calculations based on data from

Amadeus database and that of the Budapest-Capital Regional Court. Note: 'T' stands for the year of filing for bankruptcy T-1: a year before that, T-9: 9 years before filing. NI: net income, TA: total assets.

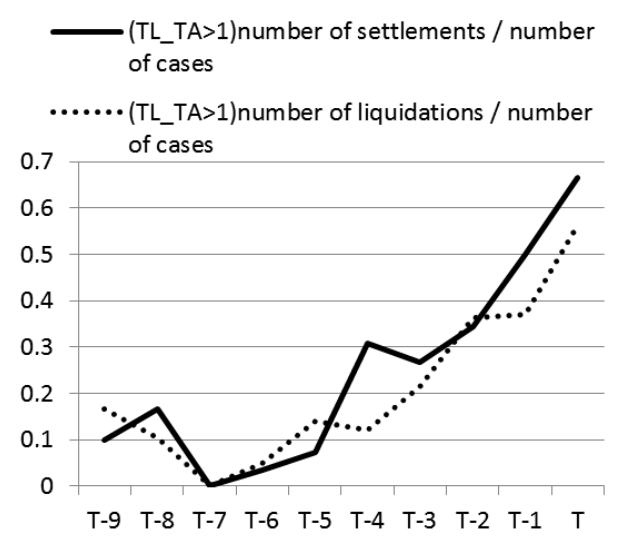

Fig. 3 Numbers of the companies in group with agreements and in group under liquidation procedures. In these cases, the companies had been in debt years before the filing for bankruptcy (TL/TA>1); Sources: Own calculations based on data from Amadeus database and that of the Budapest-Capital Regional Court. Note: 'T' stands for the year of filing for bankruptcy T-1: a year before that, T-9: 9 years before filing. TL: total liability, TA: total assets.

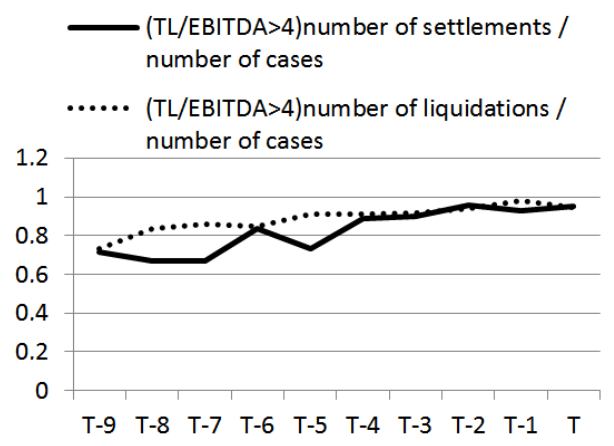

Fig. 4 Numbers of the companies in group with agreements and in group under liquidation procedures. In these cases, the long-term total liability parameters had been below the critical value years before the filing for bankruptcy (TL/EBITDA>4); Sources: Own calculations based on data from Amadeus database and that of the Budapest-Capital Regional Court. Note: ' $\mathrm{T}$ ' stands for the year of filing for bankruptcy T-1: a year before that, T-9: 9 years before filing. TL: total liability, EBITDA: Earnings before interest, tax, depreciation, and amortisation.

the expected return on equity for shareholders. This is clearly a case of value destruction.

The occurrence of this problem is relatively similar in the two groups of companies. In the year before filing for bankruptcy (T-1), 74\% of those companies which concluded an agreement in the reorganisation procedure show a profitability of below 0 . This demonstrates that this ratio is higher 


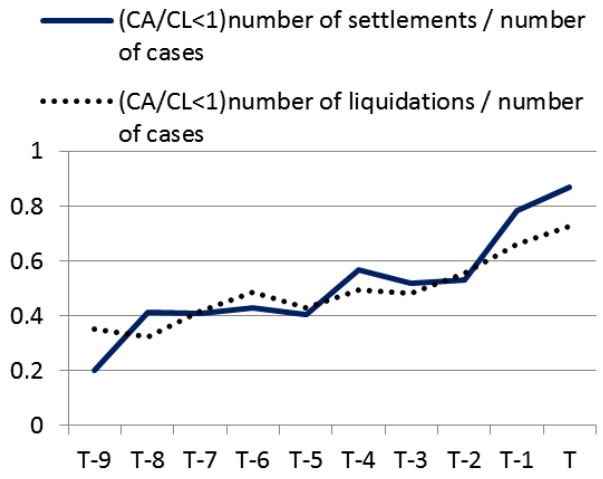

Fig. 5 Numbers of the companies in group with agreements and in group under liquidation procedures. In these cases, the short-term total liability parameters had been below the critical value years before the filing for bankruptcy ( $\mathrm{CA} / \mathrm{CL}<1$ ); Sources: Own calculations based on data from Amadeus database and that of the Budapest-Capital Regional Court. Note: 'T' stands for the year of filing for bankruptcy T-1: a year before that, T-9: 9 years before filing. CA: current assets; CL: current liability.

in this group than in the other group in which reorganisation turns into liquidation. In the 4 years before filing for bankruptcy, at least $50 \%$ of the companies in both groups were loss-making. Thus, value destruction in all these companies was constant over the previous 4 years. (see Fig. 2)

In the case of indebtedness, the applied critical value was a financial leverage ratio of $1(\mathrm{TL} / \mathrm{TA}=1)$. This fits exactly the economic criteria for filing for bankruptcy $(\mathrm{V}=\mathrm{D})$, which means that the company is only able to cover its debt (calculated on book value). The companies under reorganisation procedure seemingly underwent an increasing loss of assets before filing for bankruptcy. Interestingly, those companies which managed to conclude an agreement had had a worse (or at least as bad) picture related to indebtedness, than those which ended up in liquidation. In this latter group, only $37 \%$ of the companies had total liabilities exceeding total company assets as valued in the balance sheets (see Fig. 3).

For the determination of debt coverage ratio, the value of total liabilities (TL/EBITDA) was applied rather than the value of long-term liability (D/EBITDA). Clearly, D/EBITDA indicates the degree of "excessive lending" which shows the degree of long-term liquidity in the practice of credit rating (Damijan, 2014). Due to the lack of an efficient financial intermediary market for SMEs, the only way to get credit is often to receive commercial credit. That is why long-term liabilities are replaced by total liabilities in this case study. If this ratio is above 4 , the expected cash flow would not cover expected costs. Hence, the number of companies with a value of more than 4 for this ratio, was complemented by those companies, for which this ratio was negative because of the value of EBITDA.

Based on examination of the TL/EBITDA ratio, it can be asserted that there were no significant differences between the two distinct groups of companies before they filed for bankruptcy. From the beginning of the period that started 4 years before filing for bankruptcy, $90 \%$ of the companies had seriously suffered from problems of excessive borrowing. None of these companies would have been recommended for investment by any of the credit rating agencies (see Fig. 4).

In the case of liquidity, a short-term liquidity ratio of 1 was applied as the critical value; $\mathrm{CA} / \mathrm{CL}=1$. The result is the same as in the cases of equity efficiency and indebtedness, namely that the companies in both groups have no significantly different indicator values relating to liquidity problems for some years before filing for bankruptcy.

In brief, there is a close positive correlation in profitability, indebtedness, and liquidity indicator values for both groups of companies from the $9^{\text {th }}$ year before filing for bankruptcy onwards. The correlation coefficient seems to be fixed in all cases well above 0.8. Variation for those companies in the two distinct groups which fail to reach at least the critical value for the indicators under scrutiny above, demonstrates a similar positive correlation in the years prior to filing for bankruptcy. With merely one exception, the value of the correlation coefficient is above 0.9 .

\subsection{The reorganisation plan}

Notwithstanding the above conclusion, there may be a reorganisation plan which could push a constantly value destroying company back onto profit-making track either with the resources and assets at hand or with a serious restructuring of those assets. This requires, however, very detailed reasoning and argumentation.

The function of a reorganisation plan is to elaborate how to re-establish the liquidity of the company for continued short-term operation with due regard to the market environment and the company's potentials. This includes plans for the collecting of receivables and the sale of assets without jeopardising the short-term financing of operations to be continued. Besides that, portfolio services need to be adjusted to the (new future) market expectations and the long-term financing of the company needs to be ensured by restructuring company resources and/or by optimising 
capital leverage. Such a reorganisation plan would also indicate how to reach a profitable company structure efficiently and whether to sell the assets of the company in toto or piece by piece.

These requirements can only be met if the interested parties can make an informed decision regarding the risks relating to expected cash-flow, compared to the value of the liquidation ratio $\mathrm{V}_{\mathrm{L}}$ and $\mathrm{V}_{\mathrm{C}}$ in the case of such an alternative as a swift sale of assets.

In none of the court cases under scrutiny was there any sign of efficiency criteria in the decision-making process regarding the possibility of making settlements. There were no plans to show whether the company would have a higher value if it continued operation instead of selling its assets quickly to make payments. However, this was not relevant since the negotiations over any settlements only involved the degree of immediate or short-term repayment. Despite the aims of the bankruptcy laws, no elaborate reorganisation plan was found in the records of any of the cases at hand.

This should come as no surprise. According to the parameters detailed above, in most of the cases, filing for bankruptcy was decided on far too late, after loss of the critical status of $\mathrm{V}=\mathrm{D}$, in which there might still be a chance of an efficient last-minute reorganisation. The majority of companies under scrutiny had already been losing assets $(\mathrm{V}<\mathrm{D})$ before filing for bankruptcy regardless of whether they had made a settlement or were heading for liquidation.

A rational market participant makes decisions based on future expectations, which require a sufficient level of convincing prediction about the revitalisation ability of these companies. Yet there was no reorganisation plan at all in any of these reorganisation or settlement procedures. One may well ask: what was the motivation of the decision-makers?

\subsection{The status of companies after settlement with creditors}

According to the Amadeus database, in 2013, there were only 3 active, operating companies out of the 79 surveyed which had been registered as being under reorganisation procedure (2009-2013), whereas the court data registered only 1 such company. That means that the financially distressed companies with settlement under scrutiny did not survive more than 1-3 years after entering such an agreement. During this period all these companies were wound up, became inactive or ended up in a liquidation procedure.

As Table 2 shows, the reorganisation of the companies under scrutiny has failed. One of the lessons to be
Table 2 Status of companies filing for bankruptcy with the BudapestCapital Regional Court according to data registered at 2013

\begin{tabular}{lccc}
\hline Status of company & $\begin{array}{c}\text { Nr of } \\
\text { companies } \\
\text { with } \\
\text { settlement }\end{array}$ & $\begin{array}{c}\text { Nr of } \\
\text { companies } \\
\text { with } \\
\text { settlement }\end{array}$ \\
\hline Active & $\begin{array}{c}\text { Active/operating } \\
\text { Active/in insolvency } \\
\text { proceedings }\end{array}$ & 31 & 0.04 \\
Active & $\begin{array}{c}\text { Active others/ } \\
\text { in liquidation, } \\
\text { dissolved }\end{array}$ & 3 & 0.39 \\
Non-active & $\begin{array}{c}\text { Active/ dormant } \\
\text { Liquidation }\end{array}$ & 30 & 0.04 \\
Non-active & - & 79 & 0.38 \\
Total & - & 72 & 0.15 \\
\hline
\end{tabular}

Sources: Amadeus database and the Official Gazette

learned is that a moratorium ("credit-restructuring" or automatic stay) does not replace company reorganisation. Settlements turned into credit restructuring which, however, consisted of no more than the repayment rate of liabilities and its timing.

The primary research in 2014 shows that the new reorganisation rules do not bring any significant changes at all in the operation of bankruptcy procedures regarding the decision-making process over whether reorganisation or liquidation would better suit the case in hand. There has been no conspicuous move towards a more efficient management of financial difficulties or towards a more efficient creditor protection scheme for bankrupt Hungarian companies. The new rules, following international trends in the field, prefer corporate reorganisation process to liquidation, yet the number of companies under reorganisation procedure is negligible compared to that of those undergoing liquidation. There were no corporate reorganisation plans whatsoever in the data which could have supported the presumption that a company could be effectively readjusted to the market based on a creditors' agreement. There are only 3 companies showing some sort of business activity 1-3 years after having entered into a creditors' agreement related to a corporate reorganisation plan. It seems that the new corporate reorganisation rules provided a delaying technique/tactic for the debtors rather than promoting effective reallocations of capital.

\section{The legal background in Hungary}

Given these results, and assuming that market participants are rational actors in Hungary as well as elsewhere, one is faced with another question. Are the bankruptcy laws in Hungary efficient enough? If one considers the results 
of our research, one inevitably starts questioning the adequacy of the laws. How could it be that most of the companies that file for bankruptcy sit on negative assets for years before that moment? If the financial variables do not affect the behaviour of the directors, then what does?

After the Changes of 1990 still there were hardly any culture for bankruptcy procedures also due to the problems of the transition to a market economy. And this legacy had obvious drawbacks. There was hardly any filing for bankruptcy even in cases of need. 1990, when the socialist markets finally irreversibly collapsed, and the companies embarked upon the competitive markets, many of them became insolvent but none of them was motivated to initiate a procedure (Tarafás, 2002). The new bankruptcy laws therefore, which came into effect in 1992, initiated a huge wave of bankruptcy procedures in Hungary, because they introduced an institution of obligatory (self-) bankruptcy procedure. The purpose of these laws was primarily to provide a basis for the credibility of economic policy and to eliminate the risk of a serious liquidity crisis. This was needed to activate stakeholders in bankrupt companies and thereby leave room for manoeuvre for healthy firms. Although, paradoxically enough, obligatory bankruptcy was deemed to be an anti-market institution, the aim of it was to create the market, to clean the market. Unsurprisingly, this had many critics abroad (Bonin and Schaffer, 1996). The fact was that although the threat of obligatory bankruptcy procedure itself had a benevolent effect, it also forced otherwise viable companies into insolvency because of the suppliers' chain of debts and debt queues generated in the market transition.

Consequently, an amendment in 1993 (Act No. LXXXI of 1993) withdrew the mandatory bankruptcy procedure clause from the bankruptcy act. This also resulted, however, in the abolition of the institution of automatic stay, which again brought about the near total cessation of the formal bankruptcy (reorganisation) procedure for a further 15 years in Hungary.

Notwithstanding these problems, the bankruptcy laws of the early 1990s were intended to enhance efficient capital allocation and to protect creditors' interests in a market economy, while promoting the possible avoidance of liquidation. Interestingly, though, insolvency practices have been applied almost exclusively in liquidation procedures in the Hungarian transitionary markets, over the past 3 decades, as Fig. 6 demonstrates.

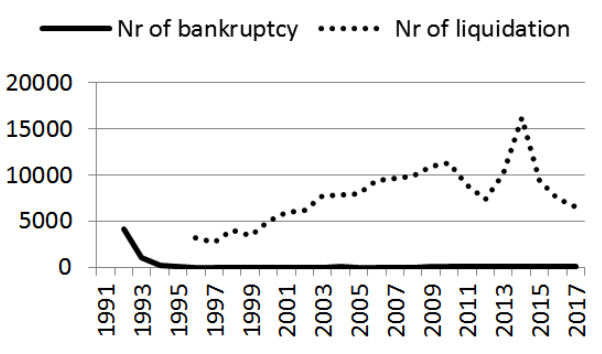

Fig. 6 Number of newly filed bankruptcy and liquidation procedures (1991-2017); Sources: KSH data; Statisztikai Tükör (2011-2018); Erdős (2007)

Clearly, the intent to reinvigorate the institution of bankruptcy in general, in Hungary, accidentally met with the aim of the globally enhanced preferences of the markets as a response to the financial crisis in 2008. The new law (Act No. LI of 2009) on reorganisation, however, was criticised right from its inception (Csőke, 2009; 2015). The priority of reorganisation procedure over liquidation was declared and the automatic stay rule was reintroduced. On the other hand, the law did not prescribe the obligation for companies filing for bankruptcy and entering reorganisation procedure to have a reorganisation plan prepared. Neither was it required that if the directors had failed to come up with any revitalisation ideas the owners should be notified immediately. This could have given owners leverage, as this process could have given them the chance to decide on time whether to file for bankruptcy and (whether or how) to negotiate with creditors. In these situations, of course, the owners could have deliberated on whether the directors should stay in position or should be changed in accordance with the wishes of creditors, or whether to introduce some form of special crisis management (Boon, 2018).

Given the missing fine-tuning of the regulations, the new modifications could obviously not guarantee a more favourable environment for reorganisations. As Fig. 6 shows, apart from the years 1991-1993, the period of obligatory bankruptcy procedure, the number of reorganisations is statistically negligible. Surely, this is not the consequence of the bankruptcy rules but that of the corporate and business culture. Whereas the owners, the managers and even the creditors know how to manage a value producing company, they cannot handle the financial problems and the lessons from the application of the crucial parameters are not learned. The participants have no interest in cooperation and have no trust in the bankruptcy procedure. 


\section{Recommendations for better information access - Pre-pack bankruptcy - automatic mandatory auction bankruptcy}

\subsection{Pre-pack bankruptcy procedure}

The pre-pack insolvency procedure is in fact an agreement developed by English bankruptcy professionals, basically as an alternative to the US Chapter 11 model. It has the advantage of a relatively quick and relatively cheap means of sale or reorganisation of the financially distressed company. In this regime, the financially distressed company, before filing for bankruptcy, negotiates the sale of the assets with the buyer in advance and then, after filing for bankruptcy, the trustee or administrator has nothing to do but to approve and to enforce the pre-negotiated contract thus agreed.

It is a package deal, since no amendment can be made by the appointed administrator during the pre-pack insolvency procedure, because, if that were possible, the renegotiations could impede achievement of the aim of a swift and workable conclusion of the procedure. And it is a pre-package deal, because the bargaining and the drafting of the agreement is prior to the company's filing for the bankruptcy. Also, the negotiations could entail a prepack sale or a pre-pack reorganisation as needed (Phillips and Kaczor, 2010), since these procedures are designed to guarantee the continuous operation of the company, as a legal successor, in either way.

As usual, the greatest advantage of this procedure is its greatest disadvantage, as a pre-pack negotiation requires neither the approval of the court nor that of the non-participant creditors. Consequently, these creditors often remain dissatisfied. On the other hand, the undisclosed nature of entering into an agreement, may enable a company to avoid negative market reactions and a consequent plummeting of its market value. This further protects employees' interests, since one of the main concerns is that they do not lose their jobs. Also, since the appointed administrator does not need to negotiate but to only enforce the contract, the process is significantly cheaper. Not only are the costs of the administrator lower but also the time spent on often frustrating negotiations regarding the bankrupt company is considerably shorter. If it is cheaper, then more assets can be distributed. Clearly, the essence of the pre-pack regime is reorganisation, and its swift, and thus less costly, accomplishment by not requiring approval of the agreement (Bork, 2012).

However, it is very likely that the consequence of this will be that those creditors who had no opportunity to get into the bargaining process will go to court. It is at this point that the problem starts. Since there is no market in these cases, the court will thoroughly scrutinise the case at hand, because it must be proven that the final negotiated price and all the other conditions of the agreement were fair. The courts, however, seem to embrace the idea of the pre-pack bankruptcy procedure. In one of the leading cases of DKLL Solicitors (DKLL Solicitors v. Her M. Revenue \& Customs [2007]EWHC $2067 \mathrm{Ch}$ ) the court approved the pre-pack sale of the debtor although it was the tax authority which could not collect in the bankruptcy procedure. Also, in another case the court endorsed the pre-pack sale of a bankrupt law firm in 4 separate contracts (Halliwellis LLP [2010]EWHC $2036 \mathrm{Ch}$ ), which clearly shows that this was not necessarily the entire company, and that certain parts of businesses may qualify as the subject matter of a pre-pack regime.

Since, obviously, pre-pack bankruptcy allows directors, even inefficiently operating directors, to remain in their positions, a pre-pack sale is more likely to be accomplished on time, when the company is still in a better shape. In any event, however, if any creditors have filed for an insolvency procedure, the pre-pack regime cannot apply.

Due to severe criticisms of this possible preferential treatment of directors at the expense of perhaps all the creditors, pre-pack bankruptcy professionals have come up with the so-called SIP 16, which is a code of practice (Statement of Insolvency Practice) to be followed in the procedure. Although they are referred to as recommendations, their use is mandatory. This procedure is supposed to guarantee the actual legal duty of the directors (fiduciary duty) towards the creditors in bankruptcy procedures.

Despite their both applying common law, the English and USA bankruptcy models are basically different: the English one is creditor-protective, whereas the American one is debtor-protective. The courts in the US model, in exchange for their approval, expect that at least $50 \%$ of the creditors representing two thirds of the total sum of debt have consented to the agreement or the reorganisation plan. In the final analysis, the same critique is valid for this regime as for the English regime

\subsubsection{Application in Hungary}

Pre-pack bankruptcy is a kind of out-of-court procedure, which makes it a useful tool for both selling and reorganising a company on the verge of bankruptcy. It may bring together the possible advantages of both formal (regulated) and informal pre-bankruptcy approaches. In addition to guaranteeing the trust of the interested parties in the bankruptcy procedure, it provides for swiftness and 
cost efficiency in drafting and enforcing a workable reorganisation plan.

International experience is quite telling, though. It has already been asserted that such a pre-pack negotiation will not work if a financially distressed company has many sceptical creditors and there is a strong asymmetry among the stakeholders (Ross et al., 2011). So even if some sort of out-of-court bankruptcy exists in most EU Member States, precisely this concern makes the Hungarian introduction of this institution materially very risky. In Hungary, most companies are SMEs, which are overwhelmingly dependent on commercial loans. This creates quite huge discrepancies in knowledge and understanding of financial markets among both businesses and managements, which inevitably lead to further informational asymmetry. Obviously, this disadvantage can be counteracted by enforcing the obligatory consent of the different classes of creditors and the obligatory approval of the court. However, such rules would demolish the benefit of swift decision making.

\subsection{Auction bankruptcy procedure}

\subsubsection{Swedish model of mandatory automatic auction bankruptcy}

The Swedish model is simple: after filing for bankruptcy an immediate, automatic, mandatory auction bankruptcy procedure takes place. From that time on, the court appoints a supervisor who acts as the agent of the company with the same fiduciary duty to the creditors as that of the directors previously had to the company. The appointee's task is to fix the estimated value of the company. In cases of doubt, independent expertise may be called on, especially if the company is to be sold in parts. The aim of the auction is to guarantee the quick sale of the company.

In certain cases, the company can be sold even before it files for bankruptcy (pre-pack auction), but in this case too, the approval of the surveillant is required. If there is only one offer, which is often a trial to buy back the company, the surveillant must look for more bidders before entering into an agreement.

One may also make an agreement with unsecured creditors. However, the absolute priority rule cannot be eschewed in these cases either, meaning that the secured creditors and certain claims (tax, wages) need to be paid up in full, the rest to a proportion of $25 \%$. This makes for quite a challenge in coming to agreement with non-secured creditors, and therefore such agreements are rare.

Since there is not much bargaining in the Swedish model, it is quick. In fact, time is the most precious commodity here. Directors must need to serve for their re-employment. This means that all employment contracts automatically terminate, or else are converted to 6-month employment contracts, and it is the new owner who decides whether to re-employ directors, which generates a definite incentive to disseminate information in time and thus make reorganisation possible.

According to the leading promoters of the Swedish mandatory automatic auction bankruptcy model, this procedure may function as a good compromise between the advantages and disadvantages of English and American pre-pack bankruptcy (Eckbo and Thoburn, 2009). Nevertheless, the most important issue in this model is, whether the buyer can efficiently reorganise the bankrupt company. And in this respect, there is a question as to which model is more efficient: the flexible Chapter 11 (Baird and Rasmussen, 2006) or this automatic but mandatory auction (Eckbo and Thoburn, 2009). It is suggested that the quickest bona fide $i$ solution is the best. That would preclude one of the biggest bankruptcy-related problems, namely the pre-calculation opportunities of directors. The auction model is useful because it can itself create a secondary market for bankrupt companies even though buying a bankrupt company is a far more complex transaction than buying a healthy one. Information asymmetry is very hard for outsiders to surmount.

Companies on the verge of bankruptcy may be profitable, but since the directors' consent is required in the case of a pre-bankruptcy sale, the bargain may be biased. However, the mandatory automatism of the auction model excludes this sort of problem.

\subsubsection{Application in Hungary}

In the transition period of the 1990s, when Hungary joined global free markets, the basic economic ideas for bankruptcy procedures were characterised by US Chapter 11 patterns. These rules, however, are designed for big companies financed by stock markets, and are less suitable for continental markets composed of companies characteristically financed by the banking systems or by commercial loans, and where SMEs with the feature of information asymmetry figure prominently. This is even more the case for Hungary where the filing for bankruptcy takes place too late $(\mathrm{V}<\mathrm{D})$.

Regarding the aforementioned challenges faced by these models, many questions remain:

1. In the undeveloped market of Hungary, would it be possible to create an efficient secondary auction market for bankrupt companies? (Dasgupta and Hansen, 2006; Klapper et al., 2006). 
2. What are the chances that the traditionally sceptical legal-administrative attitude towards the market in Hungary would undermine the entire auction procedure?

3. How efficiently would these rules change the directors' attitudes on the verge of bankruptcy?

4. Could global markets and thus EU laws have a benevolent influence on bankruptcy practices?

5. How could a timely filing for bankruptcy be achieved either by market tools or reorganisation rules so that to avoid unnecessary liquidation? (Surely, an auction procedure in late filing would only help in reducing the costs of liquidation).

\section{Conclusion}

In Hungary information needs to be provided in a much more efficient way than currently happens. Giving a second chance, in the form of reorganisation, to a bankrupt company is not necessarily an effective way to solve the efficiency problem, due to lack of information or severe information asymmetry. In a certain way, contrary to what the European Commission currently recommends, this article strives to show that the Swedish (pre-pack) auction model is best suited to circumstances in (Central-) Europe,

\section{References}

Ayotte, K., Skeel, D. A. (2010) "Bankruptcy or Bailouts", Journal of Corporate Law, 35, Article number: 469. https://doi.org/10.2139/ssrn.1362639

Baird, D. G., Rasmussen, R. K. (2006) "Private Debt and the Missing Lever of Corporate Governance", University of Pennsylvania Law Review, 154(5), pp. 1209-1251. https://doi.org/10.2307/40041322

Beck, T., Levine, R. (2004) "Stock markets, banks, and growth: Panel evidence", Journal of Banking \& Finance, 28(3), pp. 423-442. https://doi.org/10.1016/S0378-4266(02)00408-9

Bonin, J. P., Schaffer, M. E. (1996) "Bankok, vállalatok, rossz hitelek és csődök Magyarországon, 1991-1994" (Banks, firms, bad debts and bankruptcies in Hungary, 1991-1994), Közgazdasági Szemle, XLIII(2), pp. 93-113. (in Hungarian)

Boon, G. J. (2018) "Harmonising European Insolvency Law: The Emerging Role of Stakeholders", International Insolvency Review, 27(2), pp. 150-177. https://doi.org/10.1002/iir.1303

Bork, R. (2012) "Rescuing Companies in England and Germany", Oxford University Press, Oxford, UK.

Bris, A., Welch, I., Zhu, N. (2006) "The Costs of Bankruptcy: Chapter 7 Liquidation versus Chapter 11 Reorganization", The Journal of Finance, 61(3), pp. 1253-1303. https://doi.org/10.1111/j.1540-6261.2006.00872.x

Brouwer, M. (2006) "Reorganization in US and European Bankruptcy Law", European Journal of Law and Economics, 22(1), pp. 5-20. https://doi.org/10.1007/s10657-006-8978-2 under continental legal culture. The emphasis here is also on the time span. For biased information, in given cases, a swift transaction and a restart may be a fair trade off.

The most important advantage would be after all that the decision-making would be in one hand.

If one aim of bankruptcy procedure is to maximise the value of a financially distressed company, then efficient resource allocation is also an important goal in this section of the market. With automatic mandatory auction bankruptcy, the decision as to whether to reorganise or to liquidate a company may be better founded. The auction makes for a more careful deliberation of decisions and the provision of more information, at significantly lower costs, than do traditional reorganisation procedures, and this further increases the chance of more creditors being paid back. Automatic mandatory auction also enhances otherwise efficient reorganisation and thus the chance that bankruptcy be filed for in time. This strengthens trust in the market, and the protection of the creditors' interests, thereby decreasing the costs of loans. Economic growth however can only be achieved by value producing companies. As it was demonstrated, while there is lots of debate on protecting the reliability of capital markets, legislation is not pragmatic enough.

Corbae, D., D'Erasmo, P. (2017) "Reorganization or Liquidation: Bankruptcy Choice and Firm Dynamics", NBER Working Paper No. 23515. [online] Available at: https://www.nber.org/system/ files/working_papers/w23515/w23515.pdf [Accessed: 15 June 2019]

Csőke, A. (ed.) (2009) "A csődtörvény magyarázata" (Commentary on the Act on Bankruptcy). Complex Kiadó, Budapest, Hungary. (in Hungarian)

Csőke, A. (2015) "Nagykommentár a csődtörvényhez" (Grand Commentary to the Act on Bankruptcy), Wolters Kluwer Kiadó, Budapest, Hungary. (in Hungarian)

Damijan, J. P. (2014) "Corporate financial soundness and its impact on firm performance: Implications for corporate debt restructuring in Slovenia", [pdf] European Bank for Reconstruction and Development, London, UK. Available at: http://www.ebrd. com/downloads/research/economics/workingpapers/wp0168.pdf [Accessed: 15 June 2019]

Dasgupta, S., Hansen, R. G. (2006) "Auctions in Corporate Finance", In: Eckbo, B. E. (ed.) Handbook of Corporate Finance: Empirical Corporate Finance, North-Holland/Elsevier, Amsterdam, Netherlands, pp. 87-143.

de Ruysscher, D. (2018) "Legal Culture, Path Dependence and Dysfunctional Layering in Belgian Corporate Insolvency Law", International Insolvency Review, 27(3), pp. 374-397. http://doi.org/10.1002/iir.1315 
Dewaelheyns, N., Van Hulle, C. (2009) "Filtering speed in a Continental European reorganization Procedure", International Review of Law and Economics, 29(4) pp. 375-387.

https://doi.org/10.1016/j.irle.2009.03.005

Djankov, S., La Porta, R., Lopez-de-Silanez, F., Schleifer, A. (2003) "Courts", The Quarterly Journal of Economics, 118(2), pp. 453-517. https://doi.org/10.1162/003355303321675437

Eckbo, B. E., Thoburn, K. S. (2009) "Economic Effects of Auction Bankruptcy", Tuck School of Business, Hanover, NH, USA. https://doi.org/10.2139/ssrn.1387347

Erdős, K. (2007) "A magyarországi cégek és a fizetésképtelenségi eljárások föbb adatainak alakulása (1992-2007)" (Trends in the main data on firms and insolvency proceedings in Hungary (1992-2007)), [online] Available at: http://webcache.googleusercontent.com/search?q=cache:ZtQ8bHAO_SAJ:www.opmi.hu/ PHP-3/Tenyek_gazdasagrol/Vallalkozasok_szama/Csodeljarasok. $\mathrm{doc}+\& \mathrm{~cd}=1 \& \mathrm{hl}=\mathrm{hu} \& \mathrm{ct}=\mathrm{clnk} \& \mathrm{gl}=\mathrm{hu}$ [Accessed: day month year] (in Hungarian)

Gine, X., Love, I. (2010) "Do Reorganization Costs Matter for Efficiency? Evidence from a Bankruptcy Reform in Colombia", The Journal of Law \& Economics, 53(4), pp. 833-864. https://doi.org/10.1086/605848

Hungarian Centre Statistical Office "Müködő, valódi új, valódi megszűnt vállalkozások száma gazdálkodási forma szerint-GFO'02, GFO'11 (1999-2014)" (Number of enterprises in operation, real new enterprises, real dissolved enterprises by type of enterprise - GFO'02, GFO'11 (1999-2014)) [online] Available at: https://www.ksh.hu/ docs/hun/xstadat/xstadat_eves/i_qvd002b.html [Accessed: day month year] (in Hungarian)

Hungarian Centre Statistical Office "A regisztrált gazdasági szervezetek száma, 2016" (Number of registered business organisations, 2016) [online] Available at: https://www.ksh.hu/docs/hun/xftp/gyor/gaz/ gaz1612.pdf [Accessed: day month year] (in Hungarian)

Hungarian Centre Statistical Office "A regisztrált gazdasági szervezetek száma, 2017" (Number of registered business organisations, 2017) [online] Available at: https://www.ksh.hu/docs/hun/xftp/gyor/gaz/ gaz1712.pdf [Accessed: day month year] (in Hungarian)

Janda, K., Rakicova, A. (2014) "Corporate Bankruptcies in Czech Republic, Slovakia, Croatia and Serbia", [pdf] University Library of Munich, Munich, Germany. Available at: http://mpra.ub.unimuenchen.de/54109/ [Accessed: day month year]
Klapper, L., Laeven, L., Rajan, R. (2006) "Entry regulation as a barrier to entrepreneurship", Journal of Financial Economics, 82(3), pp. 591-629. https://doi.org/10.1016/j.jfineco.2005.09.006

LoPucki, L. M., Kalin, S. D. (2001) "The Failure of Public Company Bankruptcies in Delaware and New York: Empirical Evidence of a 'Race to the Bottom'", Vanderbilt Law Review, 54(2), pp. 232-282.

LoPucki, L. M., Doherty, J. W. (2015) "Bankruptcy Survival", UCLA Law Review, 62(4), pp. 970-1015.

McCormack, G., Keay, A., Brown, S., Dahlgreen, J. (2016) "Study on a new approach to business failure and insolvency. Comparative legal analysis of the Member States' relevant provisions and practices, Tender No. JUST/2014/JCOO/PR/CIVI/0075", [pdf] European Commission, Brussels, Belgium. Available at: https:// ec.europa.eu/info/sites/default/files/insolvency_study_2016 final_en.pdf [Accessed: day month year]

Pálinkó É., Pétervári K. (2020) "Economic Analysis of Recent Laws on Corporate Reorganization Methods in Hungary", In: Bilgin, M. H., Danis, H., Demir, E. (eds.) Eurasian Economic Perspectives, Springer, Cham, Switzerland, pp. 205-221. https://doi.org/10.1007/978-3-030-53536-0_15

Pálinkó, É., Tóth, T. (2017) "Hatékony csőd és reorganizáció a hazai gyakorlatban" (Efficient bankruptcy and reorganisation in practice in Hungary), Pénzügyi Szemle, 62(3), pp. 327-347. (in Hungarian)

Pétervári, K. (2018) "How to Keep a Promise: Laymen Answers to the Financial Crisis", Periodica Polytechnica Social and Management Sciences, 26(1), pp. 49-66. https://doi.org/10.3311/PPso.10427

Phillips, S., Kaczor, A. (2010) "The Benefits of UK-style Pre-packs and Comparisons with other Jurisdictions", International Corporate Rescue, 7(5), pp. 1572-1582.

Ross, S. A., Westerfield, R. W., Jaffe, J., Jordan, B. (2011) "Fundamentals of Corporate Finance", McGraw Hill Education, New York, USA.

Sowell, T. (1996) "Knowledge and Decisions", Basic Books, New York, NY, USA.

Statisztikai Tükör (Statistical Mirror), 2011-2018, 2011/20; 2013/26; 2014/30; 2015/22, Központi Statisztikai Hivatal (Hungarian Centre Statistical Office).

Tarafás, I. (2002) "Bankrendszer és monetáris politika Magyarországon 1987-2000" (Banksystem and monetary policy), Aula Kiadó, Budapest, Hungary. (in Hungarian) 